\title{
研究論文
}

\section{新薬創出等加算のメリットの要因分析と シミュレーション分析に基づく考察}

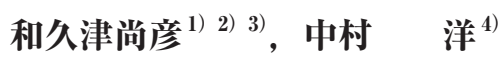

本研究は，（1）新薬創出等加算の企業側のメリットがどの程度かを把握すると共に，(2）メリッ トを $2 つ の$ 要因に分け, 各要因の大きさを分析する。また, (3) メリットの大きさが割引率や薬剤 の経済的特性によって, どの程度異なるのか感応度分析を行う。これらの分析では, 実際のデー夕 から仮想的な薬剂を設定してシミュレーションを行うと共に, 売上高推移の分布などに関する設定 パラメーター值を変更することで分析結果の頑強性を検証する。(4) 加えて, ある薬剤に対する加 算が後に上市される類似薬に与える影響（スピルオーバー効果）についても考察する。

分析から以下の結果を得た。（1）実際のデータから想定した基本ケースの場合,加算のメリットは, 累計売上高 7 \% 強の増加に換算できる。これは有用性加算 $10 \%$ 近くに相当する大きなメリットであ り,同等のメリットを実際に受けている新薬は少ない。(2) 上記のメリットの要因別分析においては, 「累計売上高 (名目值) 自体の上昇」というメリットの存在を確認しただけでなく，「現在価值法に よる将来収益割引の効果」という実質的なメリットも含めて考察した。(3)メリットの大きさ (率) は, 割引率, 需要の薬価弾力性, 販売量の変化によってあまり変わらないが, 販売量のピークアウトが 早い程, 後発品上市までの期間が長い程, あるいは（一定範囲内であれば）実勢洒格との乘離率が 高い程, 大きくなる。ただし, 乘離率は高すぎると加算対象から外れるため, 加算の維持を図る操 作を行う誘因が存在する。(4) スピルオーバー効果を含めると，加算のメリットは大幅に拡大する。

以上の分析を踏まえ，メリットの大きさ等を踏まえた政策的インプリケーションについても議論 する。

キーワード 新薬創出等加算, 薬価制度, インセンティブ, シミュレーション

\section{1.はじめに}

2010年度より「新薬創出・適応外薬解消等促進 加算」(以下，新薬創出等加算と略す）が試行導 入されている。この加算は, 後発品のない新薬に 従来より有利な条件（高い薬価）を提供すること により（図1の薬価推移(1)と(2)を参照), 企業の

\footnotetext{
1) 公益財団法人医療科学研究所

2) 一橋大学イノベーション研究センター

3) 現所属 京都大学大学院薬学研究科医薬産業政策学講座

4) 慶應義塾大学大学院経営管理研究科
}

開発費用の早期回収を容易にさせ，革新的な新薬 創出の活発化や深刻なドラッグラグの解消を意図 するものである。2014年度の薬価制度改革に向け，

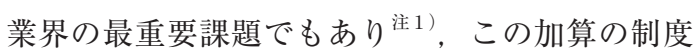
化（恒久化）が広く議論された。結局, 制度化は 見送られ，今後引き続き検討することとなった。 本研究は, 新薬創出等加算の経済的な分析により, この議論の一助となることを期待するものである。 医薬品価格や企業収益が新薬開発や新薬普及に

注1）日本製薬工業協会 (2014，24頁)。 


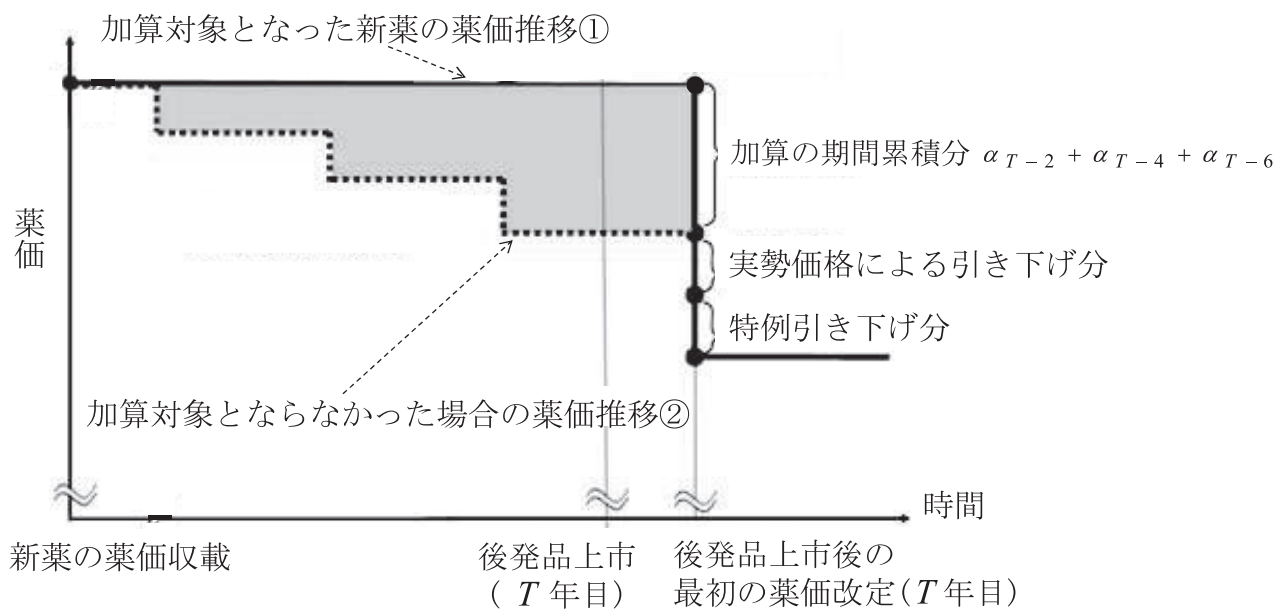

注 1 : 後発品上市までに 3 回の薬価改定がある場合。

注 $2: \alpha_{t}$ は上市後 $t$ 年目の薬価改定における加算額を表わす。

注 3 : 加算の期間累積分は必ずしも薬価推移(1)(2)差に一致しない。2.2) 節に詳述。

出所 : 厚生労働省 (2012)「新薬創出・適応外薬解消等促進加算」3 頁に加筆

\section{図 1 新薬創出等加算による薬価算定の例}

正の影響を及ぼすとする実証研究は多い。例えば, Grabowski and Vernon（1994，2000）は売上高 や内部利益, キャッシュフローなどの企業要因が 新薬開発投資と正の関係にあることを実証した。 また, Golec, Hegde and Vernon (2010) やKyle （2007）は医薬品価格を抑制する価格規制が新薬 開発投資や新薬普及にどう影響するか調べ，価格 抑圧的な規制の悪影響を確認している注2)。

しかし, 新薬創出等加算のメリットはどの程度 あるのか,メリットはどのような要因によっても たらされ, 要因別のメリットの大きさはどの程度 か，割引率や薬剤の経済的特性によってメリット の大きさはどのように変化するか, また，ある薬 剂に対する加算が後に上市される類似薬に与える 影響（スピルオーバー効果）はどの程度かなど疑 問が出てくる。

そこで本研究は, 新薬創出等加算に関する以下

注2) 医薬品価格や市場規模が新薬開発や新薬上市を促 したことを示すGiaccotto, Santerre and Vernon (2005) やDanzon, Wang and Wang (2005) らの 研究も参照のこと。
の 4 つを検討課題とする。第 1 に, 加算の企業側 のメリットがどの程度かを定量的に把握する。第 2 に, メリットを 2 つの要因に分け, 各要因の大 きさを分析する。第 3 に，加算のメリットの大き さが, 割引率や, 需要の薬価弾力性, 販売規模, 販売分布，実勢価格との乘離率，加算対象期間な どの薬剤の経済的特性によってどの程度異なる か, 感応度分析を行う。第 4 に，スピルオーバー 効果を含めると加算のメリットはどの程度となる かを分析する。

本研究では, 国内における主要医薬品や医薬品 市場のデータから，仮想的な薬剤を設定してシ ミュレーション分析を行うと共に, 設定パラメー ター值を変更することで分析結果の頑強性を検証 し，以下の結論を得た。第 1 に，実際のデー夕か ら想定した基本ケースの場合, 加算のメリットは, 累計売上高 $7 \%$ 強の増加に相当する。これは新薬 収載時, 類似薬に比し高い有効性等が認められる 場合に適用される有用性加算10\%に近いメリット に相当する。同等のメリットを実際に受けている 新薬は少ない。 
第 2 に,メリットを要因別にみると，「累計売 上高（名目值）自体の上昇」によるメリットがあ ることに加えて，「現在価值法による将来収益割 引の効果」があることで実質的なメリットは更に 大きなものになる。

第 3 に, メリットの大きさ（率）は, 割引率, 需要の薬価弾力性や販売規模の変化によってはあ まり変わらない。一方で, 加算のメリット（率）は, 販売量のピークアウトを早く迎える程, 後発品上 市までの期間が長い程，あるいは（一定範囲内で あれば)実勢価格との乘離率が高い程, 大きくなる。 ただし，乘離率は高すぎると加算対象から外れる ため, 加算の維持を図る操作を行う誘因がある。

第 4 に, スピルオーバー効果を含めると, 加算 のメリットは大幅に拡大する。

新薬創出等加算が売上高に与える影響について の分析には, 西村·粕谷 (2010) や粕谷·西村 (2011) がある。彼らは試行開始前後のデー夕を用いて加 算の市場全体への短期的な影響を分析している。 一方で, 本研究は, 個別企業の研究開発に関する 意思決定を考察するため, 個々の医薬品を対象と したミクロレベルの分析を行った。新薬創出等加 算は企業に革新的な新薬の研究開発を促す目的で 導入されたが, 実際に個別に投資するかどうかは, 個々の医薬品の期待投資収益率で判断されるため である。したがって, 新薬創出等加算の研究開発 への影響を見るには, ミクロレベルの定量分析, 具体的にはシミュレーションによる定量分析で加 算のインパクトを把握することも必要である。

また, 新薬創出等加算は後発品上市後に新薬の 薬価を引き下げることから, 本研究は加算対象期 間中だけでなく, 後発品上市後も視野に入れた, より長期的な分析を行う。

加えて, 本研究は加算のメリットの要因を明示 的に扱い,メリットの要因ごとの分析を行った。

本稿の構成は, 第 2 節で新薬創出等加算の仕組 み, 第 3 節でそのメリットの要因を説明する。第 4 節でシミュレーションの分析手法を示し, 第 5
節で分析結果を示す。最後に第 6 節でまとめを行う。

\section{2. 薬価算定方式と新薬創出等加算の仕組み}

薬価とは薬の公定価格であり, 最終需要者であ る患者ならびに保険者が薬剤費として支払う額で ある。新しく販売承認を受けた医薬品は, 国によっ て初回薬価が定められ上市される。初回薬価は, 当該医薬品の製造原価や研究開発費や一般管理 費，類似の薬効を持つ薬剤の薬価の他，海外にお ける当該医薬品の価格水準, 更には薬剤としての 画期性や有効性などを加味して決定される。上市 後は原則 2 年に一度薬価の改定を受ける。以下, 上市後の医薬品の薬価算定方式について説明す る。まず従来の制度から説明するが，これは現在 も新薬創出等加算対象外の医薬品に適用される制 度である注 3 。

\section{1）上市後の医薬品の薬価算定方式}

上市後 $t$ 年目の薬価を $p_{t}$ とし $(t \geq 1), t+1$ 年 目に薬価の改定が行われるケースを考える。薬価 の改定に当たっては，まず上市後 $t$ 年目の医療機 関への納入価格の加重平均值が, 現在の市場実勢 価格 $p_{t}{ }^{*}$ として調査され，新しい薬価 $p_{t+1}$ はこの実 勢価格 $p_{t}$ *を基に定められる。幾つかの例外はあ るものの, 多くの場合,

$$
p_{t+1}=\min \left\{p_{t}, \quad p_{t}^{*}+R p_{t}\right\}
$$

という式で定められる。 $p_{t}$ は改定前薬価, $R$ は調 整幅である。Rは現行 $2 \%$ に設定されている。改

注3) ここでは2012年度の薬価制度改革を基に説明を行う (厚生労働省, 2011, 7-9頁)。2014年度の薬価制度 改革における主な変更点は, 特例引き下げZが廃止 され，新たな特例引き下げルールZ2が導入された ことである(厚生労働省, 2013)。变更後の新たな 特例引き下げルールZ2は, 個々の状況で適用が異 なるため, 本研究における基本的な分析は 2012 年度 の仕組みを前提に行う。変更後のルールとその下で の分析は補論2を参照のこと。 
定前薬価を上限に，改定前薬価の $2 \%$ を調整幅と して実勢価格に上乗せする仕組みとなっている。

1 つの例外は, 初めて後発品が上市された後の 最初の薬価改定である。初めて後発品が上市され た後の最初の薬価改定では, 新薬は上の算定值か ら特例的な $4 \sim 6 \%$ の引き下げを受ける。後発品 上市後の最初の改定時における新しい薬価は,

$$
p_{t+1}=p_{t}^{*}+(R-Z) p_{t}
$$

となる。Zは 4 〜 \% の特例引き下げを表わす。

通常, 実勢価格は薬価より低い。薬価と実勢価 格の差，つまり薬価差は，医療機関や保険薬局の 1 つの収入源となるため, 実勢価格の引き下げ圧 力が存在する。一般に, 薬剤の革新性や同種同効 薬数などの競争環境を反映し, 競争が激しいほど, 薬価差も大きくなる注 4$) 。$ 上市後 $t$ 年目の薬価と実 勢価格の乘離率 $\mu_{t}$ を

$$
p_{t}^{*}=\left(1-\mu_{t}\right) p_{t}
$$

によって定義すると，上の算定式（1）は次のよ うに書き直せる。

$$
p_{t+1}=\min \left\{p_{t},\left(1-\mu_{t}+R\right) p_{t}\right\}
$$

この算定式の下では，乘離率 $\mu_{t}$ が $2 \%$ の調整 幅 $R$ を上回る限り，薬価は図 1 の薬価推移(2)の上 うに隔年で恒常的に下落する。また乘離率が大き いほど，薬価下落率も大きくなる。

\section{2）新薬創出等加算の仕組み}

新薬創出等加算は, 後発品のない新薬のうち一 定の条件を満たすものについて，後発品が上市さ

注4) 薬価と薬剤の革新性（イノベーション）や競争につ いての分析には, メバロチンをはじめとする脂質異 常症治療郕の市場を分析した中村（2011）などが ある。
れるまでの間，薬価の引き下げを猶予し，代わり に後発品の上市後に, 薬価の追加引下げを行う仕 組みである。この結果, 新薬創出等加算の下の薬 価推移はおおよそ，図1の推移11のようになる。 以下ではこの仕組みの具体的なルールについて説 明する注 5)。

まず，加算適用のための主な条件は，第 1 に， 薬価収載後15年以内であり後発品が収載されてい ないこと, 第 2 に, 乘離率が全収載品の加重平均 值を超えないことである。加算の適用にはどちら の条件も満たさなければならない。

加算対象期間中の新しい薬価 $p_{t+1}$ は, 改定前薬 価 $p_{t}$ を上限とする以下の式から算出される。

$$
p_{t+1}=\min \left\{p_{t},\left(1-\mu_{t}+R\right) p_{t}+0.8\left(\bar{\mu}_{t}-R\right) p_{t}\right\}
$$

$\bar{\mu}_{t}$ は調査から得る全収載品の乘離率の加重平均 值である。式中の $0.8\left(\bar{\mu}_{t}-R\right)$ は，全収載品の加 重平均乘離率から調整幅（2％）を差し引いた額 の 8 掛けを意味する。

このときの上市後 $t+1$ 年目の改定における加 算額を $a_{t+1}$ とすると， $a_{t+1}$ は，式（3）と式 (2) の差として,

$$
\begin{aligned}
\alpha_{t+1}= & \min \left\{p_{t}, \quad\left(1-\mu_{t}+R\right) p_{t}+0.8\left(\bar{\mu}_{t}-R\right) p_{t}\right\} \\
& -\min \left\{p_{t}, \quad\left(1-\mu_{t}+R\right) p_{t}\right\}
\end{aligned}
$$

と書ける。この式から, 加算額 $\alpha_{t+1}$ は, 全収載 品の加重平均乘離率と調整幅の差の 8 掛け0.8 $\left(\bar{\mu}_{t}-R\right)$ ，もしくはそれ以下ということが分かる。

したがって，加算対象にあり，かつ乘離率 $\mu_{t}$ が全収載品の加重平均值 $\bar{\mu}_{t}$ より十分に小さい新 薬は, 加算対象期間中，薬価を完全に維持する。 他方，加算対象であっても，乘離率 $\mu_{t}$ が全収載

注5）新薬創出等加算の実際の運用（特に加算の期間累 積分）について, 日本製薬工業協会の薬価グルー プにヒアリングのご協力をいただきました。記して 感謝申し上げます。 
品の加重平均值 $\bar{\mu}_{t}$ に近い場合, 改定前薬価は完 全には維持されず，薬価は加算対象期間中も緩や かだが下落することとなる。

後発品の上市を受けると, 以降の改定からは新 薬は加算対象外となり，薬価は従来の算定式 (2) の下，実勢価格に基づき定められる。

ただし，後発品上市後の最初の改定時において は, 図 1 が示すような 2 つ追加引き下げがある。 1つはこれまで引き下げを猶予されてきた分とし ての追加引き下げであり,「加算の期間累積分」 と呼ばれる。これまで受けてきた加算額の合計に 等しい。もう 1 つは従来からの特例引き下げ $Z$ (通 常 4〜6\%）である。まとめると，後発品上市後 の最初の改定時（上市後 $T$ 年目とする）における 新しい薬価は以下の算定式によって決まる。

$$
p_{T}=\left(1-\mu_{T-1}+R-Z\right) p_{T-1}-\left(\alpha_{T-2}+\alpha_{T-4}+\cdots\right)
$$

$a_{T-2}$ や $\alpha_{T-4}$ は前回や前々回の改定で受けた加 算額であり， $a_{T-2}+a_{T-4}+\cdots$ が加算の期間累積 分である。以上が新薬創出等加算の具体的な仕組 みである。

\section{3. 加算のメリットの要因}

新薬創出等加算のメリットの要因について考察 する。一般に, 企業はプロジェクト投資に際しては, プロジェクトの将来収益を割引率で割り引いてそ の現在価值によって評価し，投資の意思決定に活 用する。新薬創出等加算の場合, 企業側の加算の メリットは, 加算の下の薬価推移（図 1 の推移(1) から得られる累計売上高の現在価值と, 加算対象 とならなかったときの薬価推移（図 1 の推移(2) から得られる累計売上高の現在価值を比較した, 加算による累計売上高の上昇分の現在価值と定義 される。加算対象とならなかったときの上市後 $t$ 年 目の売上高を $S_{t}$, 加算の下の上市後 $t$ 年目の売上高 を $S_{t}^{\prime}$ とすると, 加算による累計売上高の上昇分は $\Sigma_{t}\left(S_{t}^{\prime}-S_{t}\right)$ と書ける。割引率 $r$ 一定とすると,
この上昇分の上市時点における現在価値は

$$
V=\Sigma_{t}\left(S_{t}^{\prime}-S_{t}\right) /(1+r)^{t}
$$

となる。割引率 $r$ 一定でも, 割引因子 $(1+r)^{t}$ は上市後年数 $t$ を指数に持つため, 将来に向かっ て増加的となり，遠い将来ほど大きく割り引かれ る点に注意したい。

新薬創出等加算は, ライフサイクルの早い段階 で企業に高い薬価を付与し増収させ，後の段階で 薬価を追加引き下げし減収させる。加算の下の薬 価が加算対象とならなかったときの薬価と比べ, より大きな累計売上高をもたらし， $\sum_{t}\left(S_{t}^{\prime}-S_{t}\right)>0$ となるなら，これがメリットの第 1 の要因（「累計 売上高 (名目值) 自体の上昇」による効果) となる。

加えて, 将来収益が割り引き後の現在価值で評 価されることで，メリットは更に大きくなる。た とえ加算の期間累積分が後の段階で差し引かれ, 累計売上高自体に変化がないとしても, 割り引き 後の現在価值で評価した企業の投資収益率から見 た価值は増加する。この「現在価値法による将来 収益割引の効果」がメリットの第 2 の要因となる。

\section{4. 分析手法}

新薬創出等加算は企業にとってメリットのある 制度である。だがそのメリットはどの程度なのか。 本研究は, 新薬創出等加算のメリットに関する次 の 4 つを検討課題とする。第 1 に，加算の企業側 のメリットがどの程度かを定量的に把握する。第 2 に, メリットを 2 つの要因に分け, 要因別のメ リットの大きさを分析する。第 3 に, 加算のメリッ トの大きさ (率) が, 割引率, 薬剤の経済的特性 (需要の薬価弾力性, 販売規模, 販売分布, 乘離率, 加算対象期間）によってどの程度異なるのか, 感 応度分析を行う。第 4 に，スピルオーバー効果ま で含めると加算のメリットはどの程度になるか考 察する。

国内の主要医薬品や薬価本調査のデータから, 
仮想的な薬剤を複数設定し, 数值シミュレーショ ンを行う注 6)。加算のメリットの別の分析方法と しては，この仕組みに有意なメリットがあるのか 否か, 実際のデー夕を用いて統計的な有意性を検 定する方法もある。しかしここではメリットの大 きさの把握という目的からシミュレーションを用 いることとする。結果が設定に左右されやすいと いう，シミュレーションでしばしば指摘される注 意点については, 文献や資料からパラメーター值 の設定の妥当性に注意を払うと共に, 幾つかのパ ターンを分析し結果の傾向や頑強性を確認するこ とで対処する。

\section{1）仮想的な薬剂}

本研究では, 実際のデータから以下の仮想的な 薬剤を基本ケースとして想定する。ある新薬が上 市されたとする。特許期間は 12 年とし, 直後の上 市後13年目に速やかに後発品の上市を受ける注7)。 初回薬価は 1000 円とし, 上市後 2 年以内に薬価の 改定を受け，その後は 2 年抒きの薬価の改定とす る。

薬価の推移は加算が適用されるかどうかで異な る。加算が適用されない場合， 2 年毎の全ての薬 価改定で実勢価格に基づく算定式（2）が用いら れる。

加算が適用される場合, 対象期間中の 2 年毎の 薬価改定では式 (3) が, 後発品上市後の最初の 改定時には式 (5) が, 以降の全ての改定では式 (2) が, 各々用いられるとする。特例引き下げZは, 現行の 4 〜 \%の中位をとり， $5 \%$ とする。

加算が適用されない状況として, 上市後30年間 の薬価を計算したのが, 図 2 (a) である注8)。乘 離率は, 特許期間中と失効時と失効後で異なると し $, \mu_{t}=0.06, \mu_{t}=0.12, \mu_{t}=0.1$ 選んだ。各

注6) 数值解析ソフトウェアはMatlab ${ }^{\circledR} 7.0$ (R14) を使用。

注7）小野塚（2009）によると，日本における実質特許期 間（延長前期間と延長期間の合計）は平均10.76年 である。
期間の $\mu_{t}$ の值を選ぶに当たっては, 国内の主要 医薬品の薬価データを参考にした。直近の2013年 薬価本調査によると, 全収載品の加重平均乘離率 は8.2\%である注 9)。市場平均のデータと比べて妥 当な数值と思われるが，異なる設定パラメーター 值による感応度チェックも後に行う。調整幅 $R$ は 現行の $2 \%$ あ゙あ。薬価は隔年の薬価改定の度に 下落している。特許期間中と失効後における改定 時毎の薬価下落率は, 上の対応する $\mu_{t}$ の值から $2 \%$ を差し引いた $4 \%$ と $8 \%$ である。特許失効時 の薬価下落率は, 対応する $\mu_{t} に 5 \%$ の特例引き 下げを加えた值から $2 \%$ 差し引いた15\%である。

図 2 (b) は, 図 2 (a) の薬価推移の下の仮 想的な売上高推移である。作成に当たっては，国 内の主要医薬品の売上高デー夕を参考にした（詳 しくは補論 1 を参照のこと)。売上高推移は特許 満了の 12 年目をピークとするベル型である注10)。

新薬の販売量は, 単純に売上高 $\div$ 薬価と定義す る。販売量は主として医師の科学エビデンスや対 象患者数, 市場の同種同効薬数によって決まると 仮定し ${ }^{\text {注11) }}$, 薬価に対しては非弾力的とする。よっ て, 新薬創出等加算により薬価が変わった後も販 売量に変化はないものとするが, 薬価（あるいは 相対的薬価）が販売量に影響を与えるという実証

注8) 30 年間という販売期間は，2004年時点における国内 製薬企業 7 社の売上上位70品目を調査した川上 （2005）の調査結果を参考にした。彼は，日本にお ける標準的な医薬品のライフサイクルのイメージ が, 上市後 9 年間は売上高を伸ばし続け, 発売 12 〜 13年後にピークを迎え, 発売16年目でも売上高 はピーク時の 6〜 7割を維持, 主要製品としての寿 命を終えるのは発売後 $25 ２ 6$ 年目としている。

注9)厚生労働省 (2012)。

注10) 注 8 ）を参照のこと。川上（2005）の調査結果にも 近いライフサイクルである。

注11) Iizuka（2007）は, 医師の処方行動が薬剤からの差 益に影響を受けることを示す一方で，全体的には自 己の利益より患者の自己負担により感応的としてい る。乘離率 $\mu$ は, 医療機関にとっての差益率でもあ るため, 後に行う乘離率に対する感応度分析は, 差 益率に対する感応度分析としても解釈できる。 


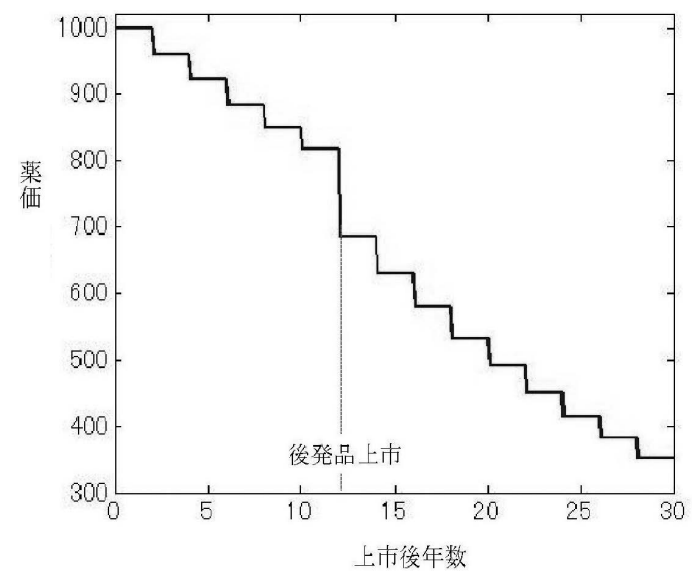

(a) 薬価推移（単位 $=$ 円）

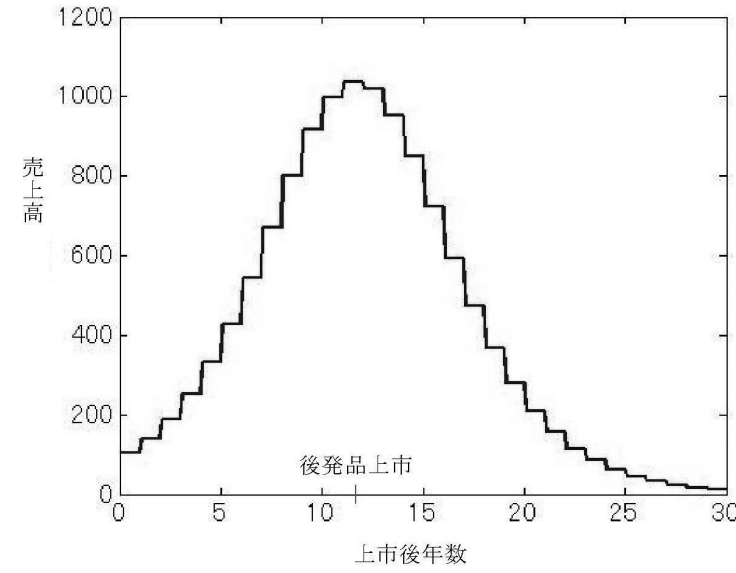

（b）売上高推移（単位 $=$ 億円）

図2 加算未適用時における仮想的な薬剤（基本ケース）

結果もあるため（西村・粕谷，2010や菅原・南部， 2014など), 需要の薬価弾力性を入れた感応度分 析も後に行う。

上市後 12 年間, 全収載品の加重平均乘離率は一 定とし，新薬の乘離率より大きいとする。具体的 には, 直近の 2013 年薬価本調査の速報值を参考に,

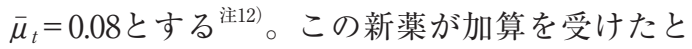
きの加算対象期間は，加算の対象条件より特許期 間と同じ 12 年となる。以上が本研究の仮想的な薬 鼡である。

\section{2）加算の補助金率}

企業の側から見た加算のメリットは，式（6）

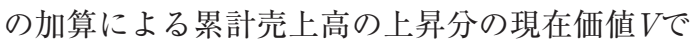
ある。これは，加算による政府から企業への「補 助金」と見なせる。加算による企業への「補助金」 が，加算の適用がなかったときの累計売上高の何 割に相当するかを示す値を「加算の補助金率」と 呼ぶなら, 加算の補助金率は,

注12）厚生労働省（2012）。

$$
\begin{aligned}
\text { 加算の補助金率 } & =\frac{V}{\sum_{t} S_{t} /(1+r)^{t}} \\
& =\frac{\sum_{t}\left(S_{t}^{\prime}-S_{t}\right) /(1+r)^{t}}{\sum_{t} S_{t} /(1+r)^{t}}
\end{aligned}
$$

と書ける。 $S_{t}$ は, 加算対象とならなかったときの 上市後 $t$ 年目の売上高, $S_{t}^{\prime}$ は, 加算の下の上市後 $t$ 年目の売上高である。本研究では式（7）に定義 する「加算の補助金率」をもって，加算のメリッ トの大きさとする。

\section{5 . 分析結果}

本研究の検討課題は以下の 4 つである。第 1 に, 新薬創出等加算の企業側から見たメリットの大き さはどの程度かを把握する。第 2 に, メリットを $2 つ の$ 要因に分け, 各要因のメリットの大きさを 分析する。第 3 に, 加算のメリットの大きさ（率） が, 割引率や薬剤の経済的特性（需要の薬価弾力 性, 販売規模, 販売分布, 乘離率, 加算対象期間） によってどの程度異なるか, 感応度分析を行う。 第 4 に， スピルオーバー効果を含めると，加算の メリットはどの程度になるのか把握する。得られ た結果は以下の通りである。 


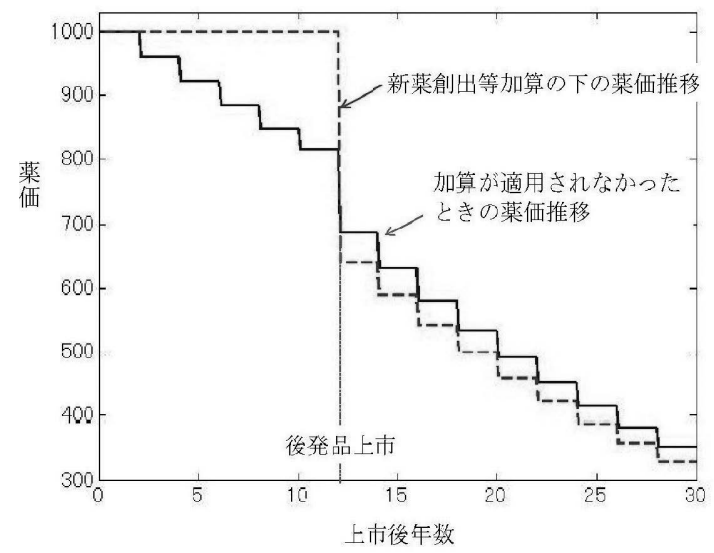

（a）薬価推移（単位 $=$ 円）

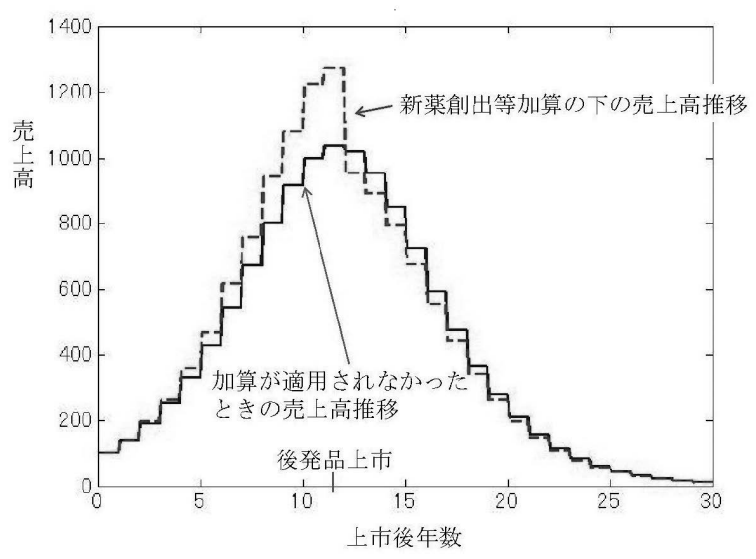

（b）売上高推移（単位 $=$ 億円）

\section{図3 基本ケースの仮想的な薬剤に加算が適用されたときの推移}

表 1 加算の補助金率と要因分析

\begin{tabular}{|c||c|c|c|c|}
\hline \multicolumn{1}{|c||}{ 割引率 } & $4 \%$ & $6 \%$ & $8 \%$ & $10 \%$ \\
\hline \multicolumn{1}{|c||}{ 加算の補助金率 } & $6.2 \%$ & $6.7 \%$ & $7.2 \%$ & $7.6 \%$ \\
\hline $\begin{array}{c}\text { 要因 } \\
\text { 分析 }\end{array}$ & \begin{tabular}{c} 
累計売上高上昇による効果 \\
\hdashline-1
\end{tabular} & \multicolumn{4}{|c|}{$4.9 \%$} \\
\hline
\end{tabular}

\section{1）メリットの大きさと要因分析}

図 3 は, メリットの大きさを測定するための前 提となる加算の下の薬価と売上高の推移である。 図中の実線は, 図 2 の再掲であり，4.1）節の仮 想的薬剤の加算未適用時の薬価と売上高の推移で ある。眓中の破線は, この仮想的薬剤の加算適用 時の薬価と売上高の推移である。

この加算の企業側のメリットはどの程度だろう か。表 1 の網掛けのコラムにあるように, 割引率 を $8 \%$ とするなら, 式 (7) から算出される加算 の補助金率は $7.2 \%$ となった注13)。

このメリットは小さいだろうか。直感的な理解 を促すため, 類似薬効比較方式の補正加算に対応

注13）割引率の值を選ぶに当たっては，医薬品開発に関す る八木 ・大久保・小野（2010）の調査報告を参考 にした。彼らは，国内で新薬（自社品）1つを上市 するのに要する開発コストを算出する際, アンケー 卜調査の結果を踏まえ割引率 $7 \%$ と $10 \%$ を用いた。 異なる割引率の下での感応度チェックも後に行う。
させてみる。累計売上高の現在価值においては, 補助金率 $7.2 \%$ というメリットは, この薬剤に $10 \%$ の補正加算がついた状況に近い注14)。もし初 回薬価に既に $5 \%$ の有用性加算が含まれていると するならば，この補助金率は15\%の補正加算にほ ぼ相当する。

実際にこれだけの有用性加算や画期性加算がつ く薬剤はどの程度あるのだろうか。表 2 にまとめ たように, 2011年〜 2012年について見てみると， この間に承認された全 84 の新医薬品の内，10\%以 上の加算がついたのは全体の約 $6 \%$ に当たる 5 つ，さらに $15 \%$ 以上の加算となると，全体の約 $3.5 \%$ を占める 3 つである。同等の加算を受けた 薬剤は少ない。

注14）有用性加算が10\%であっても，実際の加算率は，予 め定められた式により対数処理されることで下げら れるため, 表面上の加算率より低い。厚生労働省 （2014）を参照。 
新薬創出等加算のメリットの要因分析とシミュレーション分析に基づく考察

表 2 2011/12 年の補正加算適用状況

\begin{tabular}{|c||c|c|c|}
\hline 補正加算率 & $5 \%$ & $10 \%$ & $15 \%+$ \\
\hline 品目数 (全 84 品) & 7 & 2 & 3 \\
\hline 割合 & $8.3 \%$ & $2.4 \%$ & $3.5 \%$ \\
\hline
\end{tabular}

注 : 補正加算の実際の加算率は, 加算率の数值がそのま ま適用されるのではなく, 対数で処理されて計算さ れるため, 表面上の加算率より低い（厚生労働省, 2014)。

出所：『薬事ハンドブック』(2012，2013)

これらの割合は年毎に変動があるものの, 新薬 創出等加算がこの仮想的薬剤にもたらすメリット は，従来の補正加算と比べても小さくない。

このメリットを累計売上高自体の上昇による効 果と現在価值法による将来収益割引の効果に分け ると, 各要因の大きさはどの程度あるだろうか。 表 1 にあるように, 累計売上高自体の上昇による 効果は $4.9 \%$ である。割引率 $8 \%$ のときの現在価 值法による将来収益割引の効果は $2.3 \%$ である 累計売上高 (名目值) 自体の上昇というメリット があることに加えて, 現在価值法による割引の効 果もあることで，実質的なメリットは更に大きく なっている。

\section{2）割引率に対する感応度分析}

表 1 は他の割引率についての結果もまとめてい る。割引率が高くなるほど, 加算の補助金率は上 昇するが，効果は限定的と言える。

割引率が高くなるほど加算の補助金率が上昇す る理由は，割引率が高いほど，加算による後発品 上市後の売上高（名目值）の減少分が，小さく評 価されるためである。ただし，比較的遠い将来の 出来事であるため, 効果は限定的なものに留まっ ている。

\section{3）薬剂の経済的特性に対する感応度分析}

加算のメリットの大きさ（率）は, 薬剤の経済 的特性によってどの程度異なるのか。以下では, 経済的特性として, 需要の薬価弾力性, 販売規模, 販売分布, 乘離率, 加算対象期間について感応度
表 3 薬価弾力性に対する感応度分析

\begin{tabular}{|c||c|c|c|c|}
\hline 需要の薬価弾力性 & 0 & -0.065 & -0.08 & -0.095 \\
\hline 加算の補助金率 & $7.2 \%$ & $6.6 \%$ & $6.5 \%$ & $6.3 \%$ \\
\hline
\end{tabular}

表 4 販売ピークに対する感応度分析

\begin{tabular}{|c||c|c|c|c|}
\hline 販売ピーク & 6 年目 & 8 年目 & 10 年目 & 12 年目 \\
\cline { 1 - 4 } 加算の補助金率 & $9.6 \%$ & $10.0 \%$ & $9.3 \%$ & $7.2 \%$ \\
\hline
\end{tabular}

分析を行った。

（1）需要の薬価弾力性に対する感応度分析

表 3 は, 需要の薬価弾力性を加えたシミュレー ション分析の結果である。用いた弾力性值は, 西 村・粕谷（2010）の推定結果を参考にした。薬価 弾力性が -0.08 なら゙, 薬価が $1 \%$ 上昇すると, 販売量は $0.08 \%$ 減少する。需要の薬価弾力性を加 味しても，加算の補助金率は若干小さくなるもの の, 結果の傾向に大きな変化はなかった。これは, 薬価に対する弾力性值が元々大きくないことが理 由として考えられる。

\section{（2）販売規模に対する感応度分析}

次に，薬価は一定のまま，各期の売上高を $1 / n$ に比例的に変化させ, 販売量の比例的変化に対す る感応度分析を行った。対象患者数に対する感応 度分析とも解釈できる。分析の結果，加算の補助 金率は $7.2 \%$ と変化はなく, 結果の販売量の比例的 変化に対する頑強性を確認した。

(3) 販売分布に対する感応度分析 1

当該新薬の特許期間中に，異なる作用機序を持 つ類似薬が上市される場合, 当該新薬の販売量は, 特許期間中から減少しはじめるかもしれない。表 4 は, 販売量のピークアウトに対する感応度分析 の結果である。販売量のピークアウトが早いほど, 加算のメリットは大きくなる傾向がある。

理由は以下の通りである。式(7)にあるように, 加算の補助金率は，加算による累計売上高上昇分 の現在価值（分子）と, 加算の適用がなかったと きの累計売上高 (分母)の比で決まる。早期のピー クアウトは, 分子と分母どちらの売上高も減少さ 
表 5 長期収載品の販売分布に対する感応度分析

\begin{tabular}{|c||c|c|c|c|c|c|c|}
\hline & & & & 1 & 2 & $(3$ & (4) \\
\hline 販売分布 (現状比) & $+60 \%$ & $+40 \%$ & $+20 \%$ & $0 \%$ & $-20 \%$ & $-40 \%$ & $-60 \%$ \\
\hline 加算の補助金率 & $6.1 \%$ & $6.3 \%$ & $6.7 \%$ & $7.2 \%$ & $7.6 \%$ & $7.9 \%$ & $8.4 \%$ \\
\hline
\end{tabular}

注：長期収載品の販売分布の減少は，後発品の置換え率の上昇と見ることもできる。 コラム(1)の販売分布（現状）が，後発品置き換え率 10\%の販売分布とすると， コラム(2)の販売分布は, 後発品置換え率 $20 \%$ 強の販売分布に相当する。 コラム(3)の販売分布は, 後発品置換え率 $40 \%$ 強の販売分布に相当し,

コラム(4)の販売分布は，後発品置換え率 $60 \%$ 強の販売分布に相当する。

せるが，加算下においては販売量の減少は高い薬 価により一部補填されるため, 減少幅が小さくな る。この結果, 分母の方が大きく減じられるため, 一定程度までは販売量のピークアウトが早い程, 加算のメリットは高くなる傾向がある。

\section{（4）販売分布に対する感応度分析 2}

表 5 は, 長期収載品の販売分布に対する感応度 分析の結果である。薬価は一定のまま, 後発品上 市後の各期の売上高を，現状比 $\pm 20 \% ， \pm 40 \%$, $\pm 60 \%$ で変化させた。長期収載品の販売量減少が 大きい程, 加算のメリットは大きくなるが, 効果 は相対的に限定的である。

長期収載品の販売量減少が大きい程, 加算のメ リットが大きくなる理由は, 以下のように説明で きる。長期収載品の販売量が小さいほど，加算対 象とならなかったときの累計売上高（式（7）の 分母) は小さくなる。他方, 加算による累計売上 高の上昇は主として後発品上市前に生じるため, 分子に大きな変化はない。よって, 長期収載品の 販売量が小さいほど, 加算のメリットは大きくな る。相対的に大きな効果とならないのは, 比較的 遠い将来の出来事であるため, 割り引かれて評価 されるからである。

\section{（5）乘離率に対する感応度分析}

図 4 は, 乘離率に対する感応度分析の結果であ る。メリット (率) は一定範囲内であれば, 乘離 率が高いほど大きくなるが, 高すぎると全収載品 の加重平均值を超えるため, 加算対象外となり非 連続的に消滅する。よって, 革新的な薬郕やオー ファンドラッグなど, 乘離率が低い薬剤で, メリッ
卜は相対的に小さい注15)。新薬創出等加算の目的 の 1 つはオーファンドラッグの開発促進を通じた ドラッグラグの解消にあるが，この点のみを見る と政策目的への合致は弱いように見える。反対に, メリットが最も大きいのは, 乘離率が加算対象ぎ りぎりの薬剤である售16)。制度的に, 大きなメリッ トが非連続的に消滅する分, 加算の維持を図る操 作を行う誘因が存在する。

\section{（6）加算対象期間に対する感応度分析}

図 5 は, 加算対象期間に対する感応度分析の結 果である。分析の結果, 加算対象期間が長いほど, メリットは大きくなる。バイオ医薬品などは低分 子医薬品より後発品が出にくいと言われるため, メリットは大きい。

\section{4) スピルオーバー効果}

新薬創出等加算には次のようなスピルオーバー 効果も存在する。類似薬のある新薬 (新薬 $A$ ) の 初回薬価が, 類似薬効比較方式によって算定され るとする。この新薬の最類似薬 $($ 新薬 $B)$ が, 新 薬創出等加算の対象品目となっていれば, 新薬 $A$ の初回薬価は, 加算によって引き下げが猶予され

注15) オーファンドラッグの乘離率が低い例として，七レ ザイムは, ゴーチェ病の治療荗としてオーファン指 定を受けているオーファンドラッグであるが，1998 年の発売から 16 年間で，薬価はわずか $3.5 \%$ し下 落していない。

注16) 乘離率が $7 \%$ を超えるとメリットの増加が止まって いるのは, 乘離率が全収載品の加重平均值に近く なったため, 加算がついても薬価が完全には維持さ れなくなったからである。 


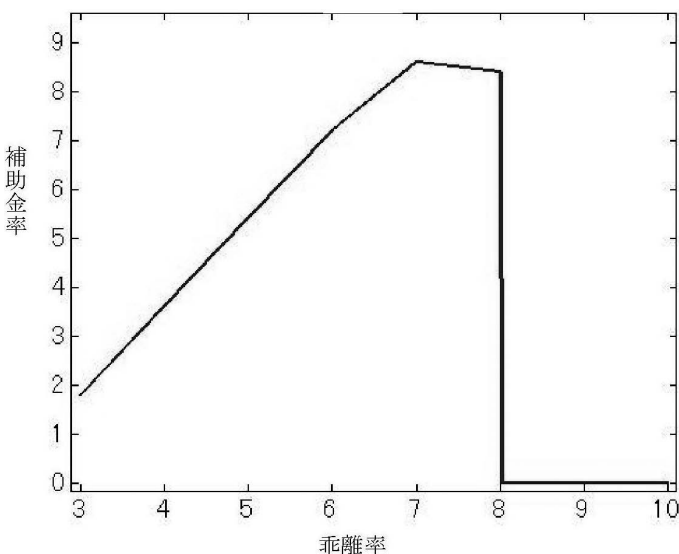

図4 乘離率に対する感応度分析

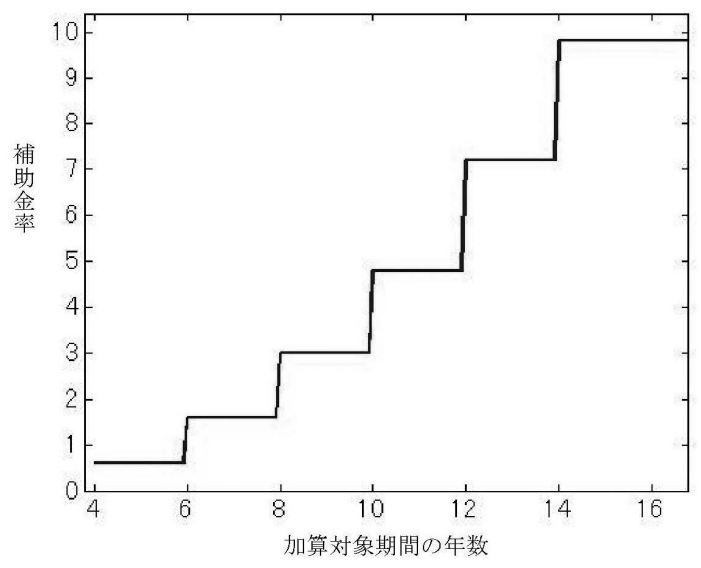

図5 加算対象期間に対する感応度分析

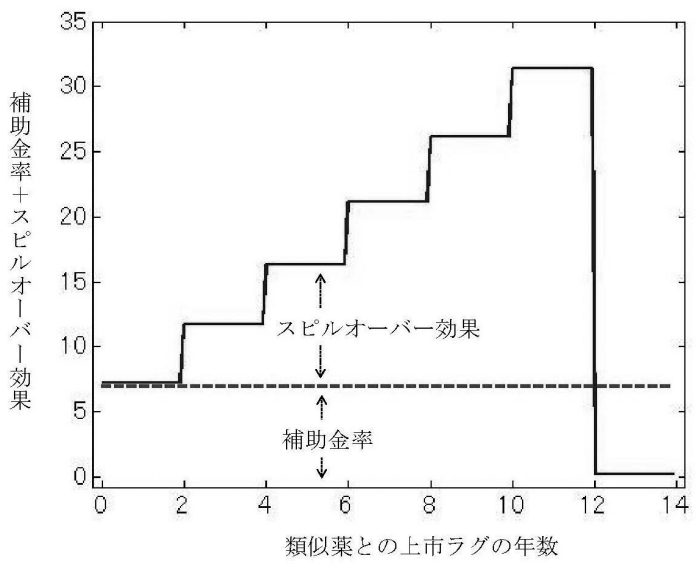

図6 スピルオーバー効果を含む加算のメリット

が大きい程，大きくなる。また，後に上市される 新薬に加算が付かなかった場合も生じる一方，先 発の類似薬がない画期性の高い新薬の場合には発 生しない。新薬創出等加算が, 革新的な新薬より も類似品のある新薬に相対的に大きなメリットを 与えるもう 1 つの側面と言え, 後者の開発インセ ンティブを与えかねない。

\section{6. 最後に}

本研究は, 新薬創出等加算の経済的な分析を 行った。具体的な検討課題ならびに分析結果は, 以下の通りである。第 1 に, 新薬創出等加算の企 新薬が加算対象品目となっている限り，上市ラグ 
業側から見たメリット (率) の定量的な把握に関 し，加算のメリットは，抒扮よそ有用性加算10\% に相当するメリットであることが示された。これ まで同等のメリットを受けている新薬は少ない。

第 2 に，加算のメリットを要因ごとに分析した 結果,「累計売上高（名目值）自体の上昇」によ るメリットがあることに加えて,「現在価值法に よる将来収益割引の効果」もあることで実質的な メリットは更に大きくなっている。

第 3 に，加算のメリット（率）が薬剤の経済的 特性（需要の薬価弾力性, 販売規模, 販売分布, 乘離率，加算対象期間）によって異なるのか頑強 性を調べた結果, 需要の薬価弾力性, 販売規模の 違いによってあまり変わらなかった。一方で，加 算のメリット (率) は, 販売量のピークアウトが 早いほど，後発品上市までの期間が長い程，ある いは（一定範囲内であれば）乘離率が高い程，大 きくなる。ただし，乘離率は高すぎると加算対象 から外れるため, 加算の維持を図る操作を行う誘 因がある。

第 4 に，加算のスピルオーバー効果についても 考察した結果, スピルオーバー効果を含めると加 算のメリットは大幅に拡大されることが示された。

一方で, 本研究のさらなる発展に向けた課題と しては，以下の点が挙げられる。第 1 に，加算を 受けた企業は，医療機関側との間で，他の薬剤の 取引において納入価格の引き下げなど相応の譲歩 を迫られるかもしれない。この場合，新たな歪み がもたらされるため, 企業の取引全体を含めた分 析が必要になる。

第 2 に, 制度化の検討には, 制度の持続可能性 を無視できない。財政の中立性を前提とすると加 算のメリットはどの程度となるのか。更なる定量 分析が必要である。

第 3 に, 加算の結果, 実際に新薬開発は促進さ れているのか。蓄積しつつあるデー夕を用いた検 証が必要だろう。

第 4 に，2014年度の薬価制度改革では特例引き
下げ $(Z)$ に関するルール変更があり，本研究で も補論として変更後のルールの下で簡単な分析を 行ったが, 長期収載品の薬価と後発品置換え率の 間にどのような関係があるかを含め, より精緻な 分析が必要だろう。

本研究の目的は, あくまで経済的な分析であり, 具体的な政策提言ではない。したがって，以下で は，ディスカッションとして，取りうる政策の方 向性についての示唆を行うことのみに止めたい。 第 1 に, 新薬創出等加算のメリットは有用性加算 率 $10 \%$ 近くに相当する大きさであったことから， その大きさを踏まえた政策的議論がなされる必要 があろう。新薬創出のためにはそのメリットの大 きさが必要であるという議論も十分考えられる。 一方で, 大きすぎるという議論であれば，加算を 制度化（恒久化）するためには，そのメリットを 小さくするか，メリットの大きさに応じた企業側 の努力を促すかの選択になろう（さらに，現在行 われている要請品目への対応だけで不十分という 議論であれば，国内の雇用や生産拡大など，企業 の状況に応じてとりうる選択肢を増やすことも検 討課題となりうる)。

第 2 に，シミュレーション分析の結果，もとも と乘離率が低く薬価の下落率が小さい薬剤は, 新 薬創出等加算のメリットが小さいことが明らかに なったため, そのような特性を持つ薬剤に対して は, 別途の研究開発支援を行うことの重要性が改 めて認識されよう（特に，そのような薬剤は，革 新的新薬あるいは希少疾病用薬剤であることが容 易に想像される)。

\section{謝辞}

本研究の作成において, 遠藤久夫教授, 飯塚敏 晃教授, 鈴木岳之准教授, そしてレフェリーの方々 より大変貴重なコメントを頂いた。ここに感謝の 意を表したい。しかし，研究の誤りの責任は筆者 にあることは言うまでもない。 


\section{補論 1 仮想的薬剂市場の作成について}

図 2 の仮想的推移は, 国内における主要医薬品 のデータを基に以下の方法で作成した。仮想的な 薬価の作成に当たっては，まず薬価デー夕を初回 薬価で基準化した。その上で, 薬価の改定が式(2) の下で行われると仮定し，算定值がデータに近似 するように, 特許期間中と失効時と失効後の乘離 值 $\mu$ を選択した。

Bass（1969）が開発したBassモデルによると, 時点 $t$ における売上高 $S(t)$ は

$$
S(t)=m\left[\frac{x \cdot(x+y)^{2} \cdot e^{-(x+y) t}}{\left(x+y \cdot e^{-(x+y) t}\right)^{2}}\right]
$$

と表わせる。一般的な解釈では， $x, y, m$ は各々， 当該製品の外的要因（革新性など）, 内的要因（評 判など), 潜在的な最大市場規模を表わすパラメー ターである。また $y>x>0$ ならば, 売上高の推 移はベル型となることも知られている。ピークの 高さは $x$ とmの值によって，ピークを迎える早さ

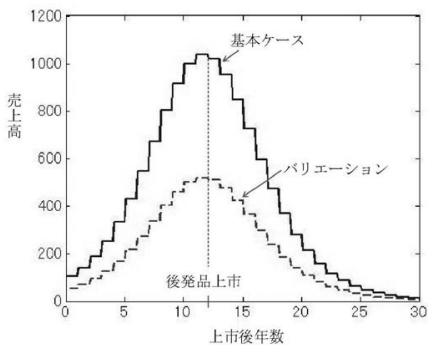

(a)

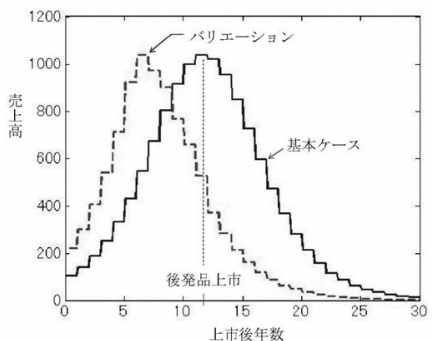

(c) はyの值によって決まる。

仮想的な売上高の作成に当たっては，まず売上 高をBassモデルで近似できると仮定し，モデル のパラメーター $x, y, m$ を最小二乗法によりデー タから推定した。パラメーターの推定に当たって は, Satoh（2001）の離散的Bassモデルを用いた。 これにより, Bassモデルの最小二乗推定でしば しば指摘される多重共線性の問題を出来る限り回 避した。

薬剤によっては, Bassモデルとは異なる売上 高推移となる可能性も考えられる。感応度分析で は, この基本ケースから売上高推移の分布に関す る設定パラメーター值を変更することにより，図 7 のような様々なケースを想定した。図（a）は, 対象患者数などの違いにより, 薬剤の市場規模が 異なるケースである。図（b）と（c）は，売上 高のピーク時期が異なるケースである。理由とし ては, 特許期間の長さや, あるいは特許期間中で も類似薬が上市されるか否かなどが挙げられる。 （図（c）は，図（b）を比例的に変化させた推移 であり，図（a）と（b）が混合したケースと見

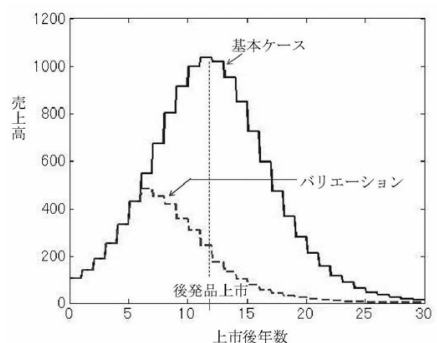

(b)

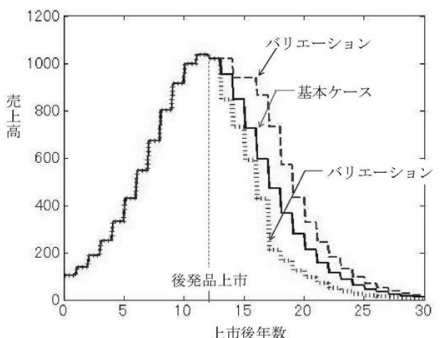

(d)

図 7 基本ケース以外の売上高推移 
なせる。）眓（d）は，後発品上市後の売上高減 少の速度が異なるケースである。基本ケースの他 に，これらのケースを想定し，各ケースで複数の バリエーションを作成した。

\section{補論 2 2014年度の薬価制度改革における変更点}

2014年度の薬価制度改革においては, 特例引き 下げZが廃止され，代わって $Z 2$ と呼ばれる新たな 特例引き下げが導入された。Z2は，後発品上市 から一定期間が経過した後の最初の改定時におい て適用される特例引き下げであり，その引き下げ 率は後発品上市から一定期間を経過した時点にお ける後発品の置換え率によって決まる。具体的に は, 後発品上市後 5 年を経過したときの後発品の 置換え率が $20 \%$ 未満ならば，引き下げ率Z2は $2 \%, 40 \%$ 未満ならば1.75\%, 60\%未満ならば1.5\% と定められている。要約すると, 新しい特例引き 下げルールZ2の下では, 後発品上市後の最初の 改定時（上市後 $T$ 年目とする）における新しい薬 価は,

$$
p_{T}=\left(1-\mu_{T-1}+R\right) p_{T-1}-\left(\alpha_{T-2}+\alpha_{T-4}+\cdots\right)
$$

となり, 後発品上市から 5 年が経過した後の最初 の改定時（上市後 $T+6$ 年目とする）における新 しい薬価は,

$$
p_{T+6}=\left(1-\mu_{T+5}+R-Z 2\right) p_{T+5}
$$

となる。以上が2014年度の薬価制度改革における 主な変更点である。

例えば，表 5 のコラム(1)から(4)の各状況に，こ の新しい特例引き下げルールZ2を適用させてみ ると，コラム(1)の状況では引き下げ率 $2 \%$ ，コ ラム (2)の状況では引き下げ率 $1.75 \%$ が，コラム(3) の状況では引き下げ率1.5\%が，コラム(4)の状況 では引き下げ率 $0 \%$ ，各々適用される。

特例引き下げZ2を適用したときの加算の補助
金率を，各状況下について計算すると，コラム (1) では7.4\%，コラム(2)では7.7\%，コラム（3)では 8.0\%，コラム(4)では8.4\%であった。薬価を一定 としているため留意が必要であるが, 表 5 の結果 から大きな変化は見られない。長期収載品の薬価 推移と後発品の置き換え率にどのような関係があ るのかも含め, より精緻な分析が課題として残さ れるものの，Z2の適用は比較的遠い将来の出来 事として割り引かれて評価されるため，実質的な 効果としては大きな変化になりにくいという基本 的な結論に変わりはないと思われる。

\section{参考文献}

Bass FM (1969) “A New Product Growth Model for Consumer Durables," Management Science. 15 (5) : 215-227.

Danzon PM, Wang YR and Wang L (2005) "The Impact of Price Regulation on the Launch Delay of New Drugs : Evidence from Twenty-Five Major Markets in the 1990s," Health Economics. 14 (3) : 269-292.

Giaccotto C, Santerre RE and Vernon JA (2005) “Drug Prices and Research and Development Investment Behavior in the Pharmaceutical Industry," Journal of Law and Economics. 48 (1) : 195-214.

Golec J, Hegde S and Vernon JA (2010) "Pharmaceutical R\&D Spending and Threats of Price Regulation," Journal of Financial and Quantitative Analysis. 45 (1) : 239-264.

Grabowski HG and Vernon JM (1994) "Return to R\&D on New Drug Introductions in the 1980s," Journal of Health Economics. 13 (4) : 383-406.

Grabowski H and Vernon JA (2000) “The Determinants of Pharmaceutical Research and Development Expenditures," Journal of Evolutionary Economics. 10 (1-2) : 201-215.

Iizuka T (2007) "Experts' Agency Problems : Evidence from the Prescription Drug Market in Japan," Rand Journal of Economics. 38 (3) : 844862.

Kyle MK (2007) "Pharmaceutical Price Controls and Entry Strategies," Review of Economics and Statistics. 89 (1) : 88-99.

Satoh D (2001) “A Discrete Bass Model and Its Parameter Estimation," Journal of the Operations Research Society of Japan. 44 (1) : 1-18.

小野塚修二 (2009)「日米における医薬品の特許期間」『政 策研ニュース』 $28: 22-24$ 
粕谷英明, 西村淳一 (2011) 「新薬創出加算による市場 への影響：2009〜2010 年度の医薬品市場のデータ から」『政策研ニュース』33:59-61

川上裕 (2005)「日米の医薬品市場における製品年齢」『政 策研ニュース』16:8-10

厚生労働省 (2011)「平成24年度薬価制度改革の骨子 (案) について」<http://www.mhlw.go.jp/stf/shingi/ 2r9852000001yrfx-att/2r9852000001yrjd.pdf>2014 年 5月8日アクセス

厚生労働省 (2012)「医薬品価格調査（薬価本調査）の速 報值について」<http://www.mhlw.go.jp/le/05Shingikai-12404000-Hokenkyoku-Iryouka/0000031539. pdf $>2014$ 年5月19日アクセス

厚生労働省（2013）「次期薬価制度改革の骨子（案）に ついて」<http://www.mhlw.go.jp/le/05-Shingikai12404000-Hokenkyoku-Iryouka/0000033639.pdf > 2014 年5月1日アクセス

厚生労働省（2014）「薬価算定の基準について」< http://www.mhlw.go.jp/le/06-Seisakujouhou12400000-Hokenkyoku/0000039400.pdf>2014 年5 月 28 日アクセス

菅原环磨, 南部鶴彦 (2014)「後発医薬品の市場シェア
決定要因と普及促進政策の効果：高脂血症薬「プラ バスタチン」における後発医薬品参入の事例」『経済 志林』81 $(2,3,4): 83-108$

中村豪 (2011)「画期的なイノベーションが競合他社の 既存製品およびイノベーション活動に及ぼす影響に ついて: 脂質異常症治療薬の事例」『東京経大学会誌』 $271: 53-82$

西村淳一, 粕谷英明 (2010)「新薬創出加算とイノベー ション」『政策研ニュース』30：13-20

日本製薬工業協会 (2014)「2014 年度実施計画」< http://www.jpma.or.jp/about/jpma_info/plan/ pdf/14plan.pdf > 2014年4月22日アクセス

八木崇, 大久保昌美, 小野俊介 (2010)「医薬品開発の 期間と費用：アンケートによる実態調査」『政策研 ニュース』29:1-9

(2014年 6 月 2 日受付, 2015 年 3 月 16 日採用)

連絡先 : 和久津尚彦

nwakutsu@pharm.kyoto-u.ac.jp 


\title{
Analyzing the Benefits from New NHI Drug Pricing System in Japan: Factor Decomposition and Simulation
}

\author{
Naohiko Wakutsu' ${ }^{12)}{ }^{3)}$, Hiroshi Nakamura ${ }^{4)}$
}

\begin{abstract}
In this paper, we analyze the benefits of a pharmaceutical firm from new NHI drug pricing system in Japan, called "NHI Drug Price Premiums for Promoting the Creation of New Drugs and the Elimination of Off-label Drug Use”. Specifically, (1) we calculate the size of the benefits from the new system from a firm's point of view and (2) decompose the benefits into sub-effects and discuss the contribution of each effect. Also, (3) we conduct sensitivity analysis to examine how the benefits from the new system change with a firm's discount rate or major economic characteristics of medicine. Moreover, (4) we consider a possible spillover effect on subsequent new drugs it may cause.

To this end, we construct several hypothetical new drugs from actual data and do numerical simulation. The results are summarized as follows. (1) A firm's benefits are calculated as a higher-than $7 \%$ increase in cumulative sales. Roughly, this is equivalent to the rate of price premium of $10 \%$ in the similar efficacy comparison method, and only a few drugs can actually win this level of price premium. (2) Factor decomposition shows that about two-thirds of the firm's benefits comes from a nominal increase in cumulative sales and the rest results from discounting future profits. (3) While the size (\%) of the benefits is barely changed with the discount rate, the price elasticity of demand or the market size, it becomes larger, the sooner is the timing of the sales peaked-out, the slower is the launch of its generic products or the larger is the deviation rate from the actual market price (unless it is beyond a certain level). Since no new drug whose deviation rate is too large is eligible for premiums, firms may find some incentives for manipulating the deviation rate to try not to lose a large premium. (4) If the spillover effect is also taken into account, the benefits from the new system is greatly increased.

Given these results of the analysis, we discuss some policy implication for the new NHI drug pricing system.
\end{abstract}

Keywords : NHI drug pricing system, premiums, R\&D incentives, simulation

\footnotetext{
1) The Health Care Science Institute

${ }^{2)}$ Institute of Innovation Research, Hitotsubashi University

${ }^{3)}$ Present address : Graduate School of Pharmaceutical Sciences, Kyoto University

${ }^{4)}$ Graduate School of Business Administration, Keio University
} 